Published in final edited form as:

Nitric Oxide. 2008 November ; 19(3): 259-265. doi:10.1016/j.niox.2008.05.002.

\title{
Dietary supplementation with cholesterol and docosahexaenoic acid increases the activity of the arginine-nitric oxide pathway in tissues of young pigs
}

\author{
Peng $\mathrm{Li}^{\mathrm{a}}$, Sung Woo Kim ${ }^{\mathrm{b}}$, Xilong $\mathrm{Li}^{\mathrm{a}}$, Sujay Datta ${ }^{\mathrm{a}, \mathrm{C}}$, Wilson G. Pond ${ }^{\mathrm{d}}$, and Guoyao Wu $\mathbf{a}^{\mathrm{a}^{*}}$ \\ aDepartment of Animal Science and Faculty of Nutrition, Texas A\&M University, College Station, TX 77843 \\ bDepartment of Animal Science, North Carolina State University, Raleigh, NC 27695 \\ cDepartment of Statistics, Texas A\&M University, College Station, TX 77843 \\ dDepartment of Animal Science, Cornell University, Ithaca, NY 14853
}

\begin{abstract}
Nitric oxide (NO), synthesized from L-arginine by tetrahydrobiopterin (BH4)-dependent $\mathrm{NO}$ synthase (NOS), is critical for neurological and muscular development and function. This study was designed to test the hypothesis that cholesterol and docosahexaenoic acid (DHA) may modulate the arginine-NO pathway in tissues of the young pig. Sixteen newborn pigs were nursed by sows for 24 $\mathrm{h}$ and then assigned to one of 4 treatment groups, representing supplementation with $0.0 \%, 0.2 \%$ cholesterol, $0.2 \%$ DHA, or cholesterol plus DHA to the basal milk-formula. All piglets were euthanized at 49 days of age. Brain, liver and gastrocnemius muscle were analyzed for BH4, NADPH and arginine, GTP cyclohydrolase-I (GTP-CH) and NOS activities, and NOS protein isoforms. Hepatic NOS activity was below the detection limit in all pigs. DHA supplementation $(P<0.01)$ increased GTP-CH activities, as well as BH4 and NADPH concentrations in brain, liver, and muscle by $24-46 \%$, while enhancing $(P<0.05)$ NOS activities by $45-48 \%$ in brain and muscle. Dietary cholesterol supplementation increased $(P<0.05)$ NOS and GTP-CH activities by $17-26 \%$ in brain but had no effect in liver or muscle. The enhanced NOS activity in the brain or muscle of cholesterolor DHA-supplemented piglets was attributable to the combined effects of increased eNOS and nNOS activation (changes in phosphorylation levels) and total iNOS protein. Additionally, DHA and cholesterol enhanced $(P>0.05)$ arginine concentrations in brain (35-42\%), but not in liver or muscle. These tissue-specific effects of cholesterol and DHA on NO synthesis may play an important role in postnatal growth and development.
\end{abstract}

\section{Keywords}

arginine; nitric oxide; pig; synthesis; guanosine triphosphate cyclohydrolase-I; tetrahydrobiopterin

Nutrients, such as dietary lipids, can influence development of the central nervous system [1, 2]. Particularly, an increase in plasma concentrations of cholesterol, which is an essential constituent of all animal cells (especially of brain) and abundant in milk, is positively associated

\footnotetext{
*Corresponding author: Dr. Guoyao Wu. Telephone +1 979845 1817; Fax +1 979845 6057;, E-mail: g-wu@tamu.edu.

Publisher's Disclaimer: This is a PDF file of an unedited manuscript that has been accepted for publication. As a service to our customers we are providing this early version of the manuscript. The manuscript will undergo copyediting, typesetting, and review of the resulting proof before it is published in its final citable form. Please note that during the production process errors may be discovered which could affect the content, and all legal disclaimers that apply to the journal pertain.
} 
with enhancement of cerebrum weight gain and behavioral development [2-4]. Additionally, docosahexaenoic acid (DHA) is a component of complex lipid in membranes, nerve insulation, as well as a precursor for signaling molecules (including prostaglandins). The availability of long-chain polyunsaturated fatty acids, including DHA, also modulates eicosanoid metabolism and myelination during growth spurt of the brain $[5,6]$. Interestingly, dietary DHA supply enhances visual and neurological development both in prematurely born infants [7] and in term infants $[8,9]$, while promoting problem-solving and childhood intelligence [10]. The beneficial influences of dietary cholesterol and DHA on brain development are currently interpreted as modification of the membrane structure and functions of membrane-associated proteins [11].

Nitric oxide (NO), synthesized from L-arginine by NO synthase (NOS), plays an important role in development and function of the brain [12]. All isoforms of the NOS [neuronal NOS (nNOS), endothelial NOS (eNOS), and inducible NOS (iNOS)] are present in neurological tissue. Of particular interest, nNOS activity is decreased when the protein is phosphorylated at the inhibition site of Ser 852, whereas eNOS activity is increased when the enzyme is phosphorylated at the activation site of Ser 1177 [12]. GTP-CH activity, Tetrahydrobiopterin (BH4), which is synthesized from GTP via the GTP cyclohydrolase I (GTP-CH) pathway [13], is an essential cofactor of NOS [14]. NO is a potent signal that regulates many physiological processes affecting behavior and cognitive function, including synaptic plasticity during long term potentiation and depression [15]. $\mathrm{NO}$ also acts as a retrograde messenger to stabilize or refine synapse during development, as a regulatory second messenger involved in the control of brain blood flow, and as an agent that contributes to both brain degeneration and neuropotection [16]. Additionally, NO promotes angiogenesis, redox state, cell immunity, and neuronal survival $[14,17]$.

Cholesterol and DHA are known to regulate NO synthesis in vascular endothelial cells [17]. We hypothesized that dietary supplementation with cholesterol and DHA can influence the arginine-NO pathway in the brain of neonatal animals. This hypothesis was tested with piglets by measuring NOS activity, total and phosphorylated levels for the three NOS isoforms, as well as concentrations of arginine, $\mathrm{BH} 4$ and NADPH in brain. To determine whether the effects of DHA and cholesterol are specific to the neuronal tissue, we also analyzed the above parameters in skeletal muscle and liver.

\section{Materials and Methods}

\section{Chemicals}

Tris, glycine, SDS, Triton X-100, Tween-20, and nitrocellulose membrane were from BioRad (Hercules, CA, USA). MOPS, SDS running buffer (20X), and NuPage 10\% Bis-Tris gel (15lane) were purchased from Invitrogen (Carlsbad, CA, USA). BCA Protein assay kit and SuperSignal ${ }^{\circledR}$ West Dura Extended Duration Substrate were procured from Pierce (Rockford, IL, USA). Mouse anti-eNOS and rabbit anti-nNOS were products of BD Biosciences (San Jose, CA, USA). Rabbit anti-phosphorylated nNOS (Ser 852) and anti-phosphorylated eNOS (Ser 1177) were obtained from Santa Cruz Biotechnology, Inc. (Santa Cruz, CA, USA) and Cell Signaling Technology (Beverly, MA, USA), respectively. Rabbit anti-iNOS was obtained from ABcam (Cambridge, MA, USA). Unless indicated, all other chemicals used in this study were purchased from Sigma-Aldrich Chemical (St. Louis, MO, USA).

\section{Animals and Diets}

Contemporary neonatal female pigs from the Texas Tech University swine herd (Lubbock, TX) were allowed to nurse their dams for 24 hours to receive colostrum, then transported to the Animal and Food Science Building and housed in individual cages in a temperature controlled room designed for neonatal pig research. They were assigned randomly within litter 
to one of four nutritionally adequate sow-milk replacer formulas containing: 1) $0.0 \%$ cholesterol and DHA, 2) $0.20 \%$ cholesterol and zero DHA, 3) zero cholesterol and $0.2 \%$ DHA, or 4$) 0.2 \%$ cholesterol and $0.2 \%$ DHA (Table 1). The experiment was performed in 4 blocks of 4 pigs each (total of 16 pigs). All diets were fed ad libitum to each individually caged pig throughout the 49 day experiment. Diets were fed in liquid form (4 parts water to 1 part dry formula) four times daily at $0800,1200,1700$, and $2200 \mathrm{hr}$ ) starting at $60 \mathrm{~mL} /$ feeding during the first day and gradually increasing to $100 \mathrm{~mL} /$ feeding by day 3 . Pigs were initially trained to eat the diet as a gruel (50\% water and 50\% dry formula on day 4; only the dry formula by day 5). Body weight of each pig will be recorded on day 1 and weekly throughout the day experiment. All pigs were euthanized at 7 weeks (day 49) with an overdose of pentbarbital. Blood samples were obtained from the jugular vein at the end of the 49-day experiment for the measurement of plasma amino acids. The cerebrum, liver and skeletal muscle of each pig were frozen immediately in liquid $\mathrm{N}$ and stored at $-80^{\circ} \mathrm{C}$ for assays of NOS and GTP-CH activities, as well as concentrations of amino acids and tetrabiopterin.

\section{Amino acid analyses}

Amino acids were determined using HPLC methods involving precolumn derivatization with ophthaldialdehyde [18]. Briefly, $100 \mathrm{mg}$ of tissue were homogenized in $2 \mathrm{ml} 1.5 \mathrm{M} \mathrm{HClO}_{4}$ and then neutralized with $1 \mathrm{ml} \mathrm{K}_{2} \mathrm{CO}_{3}$. Samples were centrifuged at $2000 \times \mathrm{g}$ for $10 \mathrm{~min}$, and the supernatant fluids were used for amino acid analysis. The HPLC system consisted of: 1) a model 600E Powerline multisolvent delivery system with $100-\mu 1$ heads, a model 712 WISP Autosampler, and a Millennium-32 workstation; 2) a model 474 scanning fluorescence detector (excitation $340 \mathrm{~nm}$, emission $450 \mathrm{~nm}$, gain 100); and 3) a Supelco $\mathrm{C}_{18}$ reverse-phase guard column $(4.6 \mathrm{~mm} \times 5 \mathrm{~cm}, 20-40 \mu \mathrm{m})$ coupled to a Supelco $\mathrm{C}_{18}$ reverse-phase column $(4.6 \mathrm{~mm}$ $\times 15 \mathrm{~cm}, 3 \mu \mathrm{m}$ ). Amino acids in samples were quantified on the basis of known amounts of standards.

\section{BH4 assay}

BH4 was analyzed by HPLC as described by Meininger and Wu [19]. Tissue ( $\sim 50 \mathrm{mg})$ was homogenized in $0.5 \mathrm{~mL}$ of $0.1 \mathrm{M}$ phosphoric acid containing $5 \mathrm{mM}$ dithioerythritol and $60 \mu \mathrm{L}$ of $2 \mathrm{M}$ trichloacetic acid (TCA). BH4 standard (50 pmol/ml) was mixed with $15 \mu \mathrm{L}$ of $0.2 \mathrm{M}$ TCA and $15 \mu \mathrm{L}$ of acidic oxidizer ( $1 \% \mathrm{I}_{2} / 2 \% \mathrm{KI}$ in $0.2 \mathrm{M} \mathrm{TCA}$ ) (acidic oxidation). After 1 -h incubation at 25 in the dark, excess iodine was removed by adding $25 \mu \mathrm{L}$ of $0 \mathrm{mg} / \mathrm{ml}$ ascorbic acid. After neutralization, $50 \mu \mathrm{L}$ of the solution was analyzed on a Phenosphere 5 ODS- 1 column $(4.6 \mathrm{~mm} \times 25 \mathrm{~cm}, 5 \mu \mathrm{m})$ using isocratic elution (flow rate of $1 \mathrm{~mL} / \mathrm{min}$ ) and fluorescence detection (excitation $350 \mathrm{~nm}$ and emission $440 \mathrm{~nm}$ ). The mobile phase solvent was 5\% HPLC-grade methonal, 95\% HPLC-water, $7.5 \mathrm{mM}$ sodium phosphate, $\mathrm{pH} 6.35$ (running time is $15 \mathrm{~min}$ ). The amount of $\mathrm{BH} 4$ in tissue extracts was determined by subtracting the amount of biopterin measured after alkaline oxidation from the amount of biopterin measured after acidic oxidation.

\section{NOS activity}

The activities of total NOS were measured as described by Meininger and Wu [19]. Tissue $(\sim 200 \mathrm{mg})$ was homogenized in $1 \mathrm{~mL}$ of $60 \mathrm{mM}$ buffer containing $1 \mathrm{mM}$ dothiothehreitol (DTT). The homogenates were centrifuged at $600 \mathrm{~g}$ for $15 \mathrm{~min}$, and the supernatant was used for NOS assays. Total NOS activity was assessed by mixing $100 \mu \mathrm{L}$ of tissue extracts with 50 $\mu \mathrm{L}$ of $8 \mathrm{mM} \mathrm{CaCl}_{2}$, and $50 \mu \mathrm{L}$ reagent mixture ( $1 \mathrm{mM}$ DTT, $1 \mathrm{mM} \mathrm{MgCl}_{2}$ ), $0.1 \mathrm{mM} \mathrm{[U-}{ }^{14} \mathrm{C}$ ] arginine $\left[5 \times 10^{3} \mathrm{dpm} / \mathrm{nmol}\right], 0.1 \mathrm{mM}$ citruline, $10 \mathrm{mM}$ valine, $0.1 \mathrm{mM} \mathrm{NADPH}, 0.1 \mathrm{mM}$ $\mathrm{BH}_{4}, 0.1 \mathrm{mM}$ FAD, $0.1 \mathrm{mM}$ FMN, $10 \mu \mathrm{g}$ calmodulin, and 0.1 M Hepes, $\mathrm{pH}$ 7.4). A blank was prepared by mixing $100 \mu \mathrm{L}$ of tissue extracts with $50 \mu \mathrm{L}$ of the reagent mixture, $25 \mu \mathrm{L}$ of 16 mM EGTA, and $25 \mu \mathrm{L}$ of $16 \mathrm{mM} \mathrm{L}$-monomethylarginine. All assay tubes were incubated at 
$37 \mathrm{C}$ for $30 \mathrm{~min}$. Reactions were terminated by addition of $50 \mu \mathrm{L}$ of $1.5 \mathrm{M} \mathrm{HClO} 4$. Neutralized solution $(0.5 \mathrm{~mL})$ was loaded into an AG50W-X8 resin $(\mathrm{Na}+$ form $)$ column $(0.55 \times 6 \mathrm{~cm})$, and the column eluted with $4 \mathrm{~mL} \mathrm{H}_{2} \mathrm{O}$. The elute containing $\left[{ }^{14} \mathrm{C}\right]$ citrulline was measured for radioactivity. NOS activity was calculated on the basis of $\left[{ }^{14} \mathrm{C}\right]$ citrulline production and medium $\left[{ }^{14} \mathrm{C}\right]$ arginine specific activity (SA).

\section{GTP-CH activity}

The GTP-CH activity was determined as described by Meininger and Wu [19]. Tissue ( 200 $\mathrm{mg}$ ) was homogenized in $1 \mathrm{~mL}$ of $100 \mu \mathrm{L}$ phenylmethylsulfonyl fluoride in $0.1 \mathrm{M}$ Tris buffer $(\mathrm{pH} 7.8,0.3 \mathrm{M} \mathrm{KCl}, 2.5 \mathrm{mM}$ EDTA, 10\% glycerol). The tissue homogenates were centrifuged at $600 \mathrm{~g}$ for $15 \mathrm{~min}$. The supernatant was loaded into a Sephadex G-25 column $(5 \times 60 \mathrm{~mm})$. The column was washed with $0.45 \mathrm{~mL}$ of $0.1 \mathrm{M}$ Tris buffer. An additional $0.5 \mathrm{~mL}$ of $0.1 \mathrm{M}$ Tris buffer was added to the column, and the eluate was collected for GTP-CH assay to eliminate amino acids, biopterin and NADPH) that potentially interfere with the assay. The desalted enzyme preparation $(200 \mu \mathrm{L})$ was mixed with $100 \mu \mathrm{L}$ of $6 \mathrm{mM} \mathrm{GTP}$ at $37 \mathrm{C}$ in the dark for $90 \mathrm{~min}$ before adding $25 \mu \mathrm{L}$ of $1 \% \mathrm{I} 2 / 2 \% \mathrm{KI}$ in $1 \mathrm{M} \mathrm{HCl}$. A separate blank was prepared with $200 \mu \mathrm{L}$ of desalted enzyme preparation and $25 \mu \mathrm{L}$ of $1 \% \mathrm{I} 2 / 2 \% \mathrm{KI}$ in $1 \mathrm{M} \mathrm{HCl}$. After 5 min incubation, $100 \mu \mathrm{L}$ of $6 \mathrm{mM}$ GTP was added to the bland tube. After centrifugation, the supernatant was mixed with $25 \mu \mathrm{L}$ of $1 \%$ ascorbic acid and then neutralized with $25 \mu \mathrm{L}$ of 1 $\mathrm{M} \mathrm{NaOH}$. After a 60-min incubation with alkaline phosphatase at $37 \mathrm{C}$ in the dark, samples were analyzed for neopterin by HPLC as described for BH4 determination.

\section{NADPH analysis}

NADPH was analyzed using HPLC, as described by Wu et al. [20]. Tissue ( 100 mg) was homogenized in $1 \mathrm{ml}$ of ice-cold $1 \mathrm{mM}$ bathophenanthrolinedisulfonic acid (BPTD)/250 mM $\mathrm{KOH}$, followed by addition of $0.25 \mathrm{ml}$ of ice-cold $1 \mathrm{M} \mathrm{KH}_{2} \mathrm{PO}_{4}$ and $1 \mathrm{ml} 1 \mathrm{mM}$ BPTD (in 150 $\mathrm{mM}$ potassium phosphate buffer, $\mathrm{pH}$ 7.5). The solution was centrifuged at 10,000 $\mathrm{g}$ for $1 \mathrm{~min}$, and an aliquot of the supernatant $(25 \mu \mathrm{l})$ was analyzed on a Phenosphere 5 ODS-1 column (4.6 $\times 25 \mathrm{~cm}, 5 \mu \mathrm{m}$ ) using isocratic elution (flow rate of $1 \mathrm{ml} / \mathrm{min}$ ) and fluorescence detection (excitation $340 \mathrm{~nm}$ and emission $460 \mathrm{~nm}$ ). The mobile phase solution is $150 \mathrm{mM}$ potassium phosphate $/ 5 \mathrm{mM}$ tetrabutylammonium hydrogen sulfate/23\% methanol (running time is 10 $\min )$.

\section{Western blotting for NOS in brain and muscle}

Brain and muscle were pulverized in liquid nitrogen and homogenized in lysis buffer containing $20 \mathrm{mM}$ Tris- $\mathrm{HCl}$ (pH 7.4), $50 \mathrm{mM} \mathrm{NaCl}, 50 \mathrm{mM} \mathrm{NaF}, 50 \mathrm{mM}$ EDTA, $1 \%$ Triton X-100, 1x protease inhibitor cocktail, and 1x phosphatase inhibitor cocktail (Calbiochem, La Jolla, CA). Proteins in homogenates were determined using the Pierce BCA Protein Assay Kit. The samples were subsequently diluted with $2 x$ Laemmli buffer $(125 \mathrm{mM}$ Tris- $\mathrm{HCl} \mathrm{pH} 6.8,4 \%$ w/ v SDS, $10 \%$ 2-mercaptoethanol, $12 \%$ glycerol, and $0.004 \%$ w/v bromphenol blue) and heated in boiling water for $5 \mathrm{~min}$. NuPage 10\% Bis-Tris gel (Invitrogen) was used for SDS-PAGE separation of proteins ( 60 and $30 \mu \mathrm{g}$ for brain and muscle samples, respectively). Proteins were transferred to a nitrocellulose membrane under $12 \mathrm{~V}$ overnight, using the Bio-Rad Transblot apparatus. Membranes were blocked in 5\% fat-free dry milk in TTBS $(20 \mathrm{mM}$ Tris $/ 150 \mathrm{mM}$ $\mathrm{NaCl}, \mathrm{pH} 7.5$, and $0.1 \%$ Tween-20) for $3 \mathrm{~h}$ and then were incubated with the primary antibody for eNOS $(1: 1000)$, nNOS $(1: 1000)$, or iNOS $(1: 1000)$ overnight at $4^{\circ} \mathrm{C}$ with gentle shaking. After washed three times with TTBS, the membranes were incubated at room temperature for 2-3 h with a secondary antibody (peroxidase-labeled donkey anti-rabbit or anti-mouse IgG, Jackson Immuno Research, 1:50,000). Finally, the membranes were washed with TTBS, followed by development using Supersignal West Dura Extended Duration Substrate according to the manufacturer's instructions (Pierce, Rockford, IL). The signals were detected on Fujifilm 
LAS-3000 (Tokyo, Japan). Results were expressed as relative pixel intensities (arbitrary unit, $\mathrm{AU}$ ). Equal numbers of samples from various tissues were always run on the same gel to ensure consistency. Values from replicate gels were normalized to an arbitrary value for a pooled sample included on every gel.

\section{Statistical analysis}

Data were subjected to two-way factorial ANOVA. Differences in treatment means were determined using the Student-Newman-Keuls multiple comparison test. $P<0.05$ was taken to indicate statistical significance.

\section{Results}

\section{Arginine and citrulline concentrations in tissues}

Dietary supplementation with DHA and cholesterol increased $(P<0.01)$ concentrations of arginine in the brain (35-42\%), but not in the skeletal muscle of neonatal piglets (Table 2). Cholesterol, not DHA, decreased $(P<0.01)$ arginine concentration in the liver. Interestingly, DHA, not cholesterol, enhanced $(P<0.01)$ arginine concentration in plasma $36 \%$ (Table 2 ). In contrast, both DHA $(P=0.05)$ and cholesterol decreased $(P=0.0001)$ citrulline concentration in the brain, but not in the liver, muscle or plasma (Table 2).

\section{NOS activity in tissues}

NOS activity was below the detection limit in the livers of all pigs. Dietary cholesterol supplementation increased $(P<0.05)$ NOS by $17 \%$ in the brain but, had no effect in skeletal muscle. Remarkably, DHA supplementation enhanced $(P<0.001)$ NOS activities by $45-48 \%$ in brain and muscle. No significant interaction of dietary cholesterol and DHA on NOS activity was observed in either brain or muscle of neonatal pigs (Table 3).

\section{GTP-CH activity in tissues}

Dietary supplementation with cholesterol increased $(P<0.01)$ GTP-CH activities by $26 \%$ in the brain but had no effect in liver or muscle. In contrast, DHA supplementation enhanced $(P<0.001)$ GTP-CH activity by $21.7 \%, 23.2 \%$ and $40 \%$ in the brain, liver and muscle, respectively. No significant interaction of dietary cholesterol and DHA on GTP-CH activity was observed in either the brain or the muscle of piglets (Table 3 ).

\section{BH4 and NADPH concentrations in tissues}

Dietary supplementation with cholesterol had no effect on BH4 or NADPH concentrations in the brain, liver, or skeletal muscle, although there was a trend $(P<0.10)$ of increased BH4 in the brain of cholesterol-supplemented pigs. In contrast, DHA supplementation $(P<0.01)$ increased BH4 concentrations in the brain, liver, and muscle by $29.0 \%, 31.4 \%$ and $49 \%$, respectively (Table 3). No significant interaction of dietary cholesterol and DHA on BH4 concentrations was observed in either the brain or muscle of young pigs (Table 3).

\section{Total amounts of nNOS, eNOS, and iNOS proteins, as well as phosphorylated nNOS (Ser 852 ) and eNOS (Ser 1177) in brain}

Dietary supplementation of cholesterol or DHA did not affect total amounts of nNOS or eNOS protein in brain (Fig 1A, 1C). However, both cholesterol and DHA reduced $(P<0.05)$ the level of phosphorylated nNOS at the inhibition site of Ser 852 (Fig 1B), therefore resulting in increased activity of the protein. In addition, total amount of iNOS protein was enhanced $(P<$ 0.05 ) in the brain of piglets supplemented with either cholesterol or DHA (Fig 1E). Phosphorylation of eNOS in brain was increased $(P<0.05)$ by dietary supplementation of DHA or DHA plus cholesterol (Fig 1D). 


\section{Total amounts of nNOS, eNOS, and iNOS proteins, as well as phosphorylated nNOS (Ser 852) and eNOS (Ser 1177) in skeletal muscle}

Total amounts of nNOS or iNOS in gastrocnemius muscle were not affected by cholesterol or DHA supplementation (Fig 2A, 2E). In contrast, dietary cholesterol, not DHA, induced dephosphorylation of nNOS at the inhibition site of Ser 852 (Fig 2B), therefore increasing the enzyme activity. Dietary supplementation of DHA tended to increase total amounts of eNOS protein and enhanced $(P<0.05)$ the level of phosphorylated eNOS at Ser 1177 in muscle (Fig 2C, 2D).

\section{Discussion}

Cholesterol and DHA play a critical role in neonatal brain development and function [10]. However, potential influences of these lipids on the production of secondary messengers and downstream signaling pathways remain largely unknown. Results of the present study indicate that dietary supplementation with DHA or cholesterol enhanced NOS and GTP-CH activities, as well as $\mathrm{BH}$ and arginine concentrations in piglet brain. While DHA supplementation also increased GTP-CH activities and BH4 concentrations in liver and skeletal muscle, as well as NOS activity in muscle, dietary cholesterol supplementation did not affect NOS or GTP-CH activity in the two tissues. Also, cholesterol or DHA treatment had no effect on arginine concentrations in either liver or muscle. Thus, there are tissue-specific effects of cholesterol and DHA on NO synthesis in young pigs, which may play an important role in postnatal growth and development of the brain. To our knowledge, this is the first report of dietary supplementation with DHA or cholesterol on the arginine-NO pathway in any animal species.

The brain expresses predominantly nNOS and, to a lesser extent, eNOS, whereas skeletal muscle contains both isoforms of the NOS [22]. eNOS and nNOS activities can be regulated by phosphorylation of serine or threonine residues. Of particular interest, eNOS is activated by phosphorylation at Ser 1177, but inhibited by phosphorylation at Thr 495 [12]. Additionally, nNOS is inhibited by phosphorylation at Ser 852 [12]. Function of potential phosphorylation on other sites, such as of nNOS (Ser 847, 1416, 1417) or eNOS (Ser 113), has not been defined. Studies over the past decade have demonstrated that dietary factors play an important role in regulating NOS expression in a cell- and tissue-specific manner [17]. In support of this view, NOS activity in the brain, liver and muscle was differentially affected by dietary DHA and cholesterol. Our observation that a combination of the two did not result in either potentiation or an additive effect suggests that the NOS activity reached a peak following feeding with both cholesterol and DHA. Furthermore, results of western blot analyses indicated that increased NOS activity in both brain and muscle of DHA-supplemented piglets was attributable to enhanced phosphorylation of eNOS at the activation site (Ser 1177) (Fig. 1). Additionally, DHA induced dephosphorylation of brain nNOS at the inhibition site (Ser 852) (Fig. 1), which can also activate the enzyme. These findings suggest a novel and important role for DHA in post-translational regulation of NOS activity. Interestingly, iNOS expression in piglet brain was enhanced by both cholesterol and DHA supplementation (Fig. 1), but the physiological significance of this observation is currently unknown.

$\mathrm{BH}_{4}$ has long been recognized as a cofactor for all isoforms of NO synthase [23]. This biopterin helps stabilize the dimerization of every isoform of NOS and also plays a redox role in its catalytic reaction. A deficiency of $\mathrm{BH}_{4}$ results in an uncoupling of NOS for $\mathrm{NO}$ generation and subsequent production of superoxide from oxygen. This has important implications for cellular oxidative stress, a major factor responsible for endothelial dysfunction [24]. Thus, a deficiency of BH4 in the brain results in impaired neurological development, as well as neurological disorders, including Alzheimer's disease, Parkinson's disease, and depression [25]. In mammalian cells, GTP-CH is the first and rate-controlling enzyme in de novo synthesis of $\mathrm{BH}_{4}$ [22]. Recent studies reveal that arginine stimulates expression of GTP-CH in cells, 
thereby increasing the amount of GTP-CH protein [22,26,27]. Consistent with this notion, an increase in concentrations of arginine was associated with an increase in GTP-CH activity in the brain of piglets. Additionally, a similar result was obtained for skeletal muscle. The Km values of various isoforms of the NOS for arginine are 3-10 $\mu \mathrm{M}$ [14], whereas intracellular concentrations of arginine are $250-2000 \mu \mathrm{M}$ in tissues (including the brain and muscle). Thus, NOS is well saturated with arginine under physiological conditions. However, increasing concentrations of arginine from 0.1 to $10 \mathrm{mM}$ dose-dependently enhances NO synthesis in mammalian cells [22]. We have suggested that this arginine paradox for NO production can be explained by an increase in BH4 availability in response to stimulation of GTP-CH expression by arginine [17].

NADPH, another essential co-factor for all isoforms of the NOS, provides electrons necessary for NO synthesis [14]. Therefore, the regulation of cellular NADPH levels plays an important role in modulating NO production [17]. We found that dietary supplementation with DHA increased concentrations of NADPH in the brain, liver and skeletal muscle of pigs. Similarly, other investigators previously reported that dietary supplementation with $n-3$ polyunsaturated fatty acids increased NADPH levels in rat liver and adipose tissue [28]. It is possible that DHA stimulates expression of glucose-6-phosphate dehydrogenase, a rate-controlling enzyme of the pentose cycle, in pig tissues. Alternatively, cholesterol or DHA may inhibit the oxidation of NADPH by NADPH oxidase in the brain, as reported for endothelial cells treated with n-3 polyunsaturated fatty acids [17]. Nonetheless, in view of the crucial role for NO in neurological function [15], the coordination of increases in concentrations of NADPH, along with BH4 availability and NOS activity, ensures an augmented production of NO in the brain of cholesterol- and DHA-supplemented young pigs.

In conclusion, the results of the present study demonstrate that dietary supplementation with DHA and cholesterol increased NOS and GTP-CH activities, as well as BH4 and NADPH concentrations in the brain of young pigs. In addition, cholesterol supplementation enhanced the activity of the arginine-NO pathway in the brain, but not in the liver or skeletal muscle.

These tissue-specific effects of cholesterol and DHA on NO synthesis may play an important role in neurological growth and development of neonates.

\section{Abbreviations used}

BH4, tetrahydrobiopterin; DHA, docosahexaenoic acid; GTP-CH, guanosine triphosphate cyclohydrolase-I;; NO, nitric oxide; NOS, nitric-oxide synthase; eNOS, endothelial nitricoxide synthase; iNOS, inducible nitric-oxide synthase; nNOS, neuronal nitric oxide synthase.

\section{Acknowledgment}

This work was supported, in part, by Texas AgriLife Research H-8200), North Carolina State University, National Research Initiative Competitive Grants (no. 2003-35206-13694 and 2008-35206-18764) from the USDA Cooperative State Research, Education, and Extension Service, and National Institutes of Health (no. R25-CA90301). We thank all research personnel in our laboratories for technical assistance, as well as Ms. Frances Mutscher for office support.

\section{References}

1. Pond WG. Dietary fatty acids and cholesterol in normal brain development: Comments. Theor. Biol 2003;8:37-68.

2. Pond WG, Mersmann HJ, Su D, McGlone JJ, Wheeler MB, Smith EO. Neonatal Dietary Cholesterol and Alleles of Cholesterol 7- $\alpha$ Hydroxylase Affect Piglet Cerebrum Weight, Cholesterol Concentration, and Behavior. J. Nutr 2008;138:282-286. [PubMed: 18203892] 
3. Boleman SL, Graf TL, Mersmann HJ, Su DR, Krook LP, Savell JW, Park YW, Pond WG. Pigs fed cholesterol neonatally have increased cerebral cholesterol as young adults. J Nutr 1998;128:24982504. [PubMed: 9868199]

4. Schooknecht PA, Ebner S, Pond WG, Zhang S, McWhinney V, Wong W, Klein PD, Dudley M, Goddard-Finegold J, Mersmann HJ. Dietary cholesterol supplementation improves growth and behavioral response of pigs selected for genetically high or low serum cholesterol. J. Nutr 1994;124:305-314. [PubMed: 8308581]

5. Martinez M. Tissue levels of polyunsaturated fatty acids during early human development. J. Pediatr 1992;120:S129-S138. [PubMed: 1532827]

6. Koletzko B, Rodriguez-Palmero M. Polyunsaturated fatty acids in human milk and their role in early infant development. J. Mammary Gland Biol. Neoplasia 1999;4:269-284. [PubMed: 10527469]

7. Carlson SE, Werkman SH, Rhodes PG, Tolley EA. Visual-acuity development in healthy preterm infants: effect of marine-oil supplementation. Am. J. Clin. Nutr 1993;58:35-42. [PubMed: 8317386]

8. Birch EE, Hoffman DR, Uauy R, Birch DG, Prestidge C. Visual acuity and the essentiality of docosahexaenoic acid and arachidonic acid in the diet of term infants. Pediatr. Res 1998;44:201-209. [PubMed: 9702915]

9. SanGiovanni JP, Parra-Cabrera S, Colditz GA, Berkey CS, Dwyer JT. Meta-analysis of dietary essential fatty acids and long-chain polyunsaturated fatty acids as they relate to visual resolution acuity in healthy preterm infants. Pediatrics 2002;105:1292-1298. [PubMed: 10835071]

10. Willatts P, Forsyth JS, DiModugno MK, Varma S, Colvin M. Effect of long-chain polyunsaturated fatty acids in infant formula on problem solving at 10 months of age. Lancet 1998;352:688-691. [PubMed: 9728984]

11. Fleith E, Clandinin MT. Dietary PUFA for preterm and term infants: review of clinical studies. Crit. Rev. Food Sci. Nutr 2005;45:205-229. [PubMed: 16048149]

12. Moncada S, Bolanos JP. Nitric oxide, cell biogenesis and neurodegeneration. J. Neurochem 2006;97:1676-1689. [PubMed: 16805776]

13. Shi WJ, Meininger CJ, Haynes TE, Hatakeyama K, Wu G. Regulation of tetrahydrobiopterin synthesis and bioavailability in endothelial cells. Cell Biochem. Biophys 2004;41:415-433. [PubMed: 15509890]

14. Wu G, Morris SM. Arginine metabolism: nitric oxide and beyond. Biochem. J 1998;336:1-17. [PubMed: 9806879]

15. Bredt DS, Snyder SH. Nitric oxide: a physiological messenger molecule. Ann. Rev. Biochem 1994;63:175-195. [PubMed: 7526779]

16. Mize RR, Dawson TM, Dawson VL, Friedlander MJ. Nitric oxide in brain development, plasticity and disease. Prog. Brain Res 1998;116:1-2.

17. Wu G, Meininger CJ. Regulation of nitric oxide synthesis by dietary factors. Ann. Rev. Nutr 2002;22:61-86. [PubMed: 12055338]

18. Wu G, Meininger CJ. Analysis of citrulline, arginine, and methylarginines using high-performance liquid chromatography. Methods Enzymol 2008;440:177-189. [PubMed: 18423217]

19. Meininger CJ, Wu G. Regulation of endothelial cell proliferation by nitric oxide. Mthods Enzymol 2002;352:280-295.

20. Wu G, Haynes TE, Li H, Yan W, Meininger CJ. Glutamine metabolism to glucosamine is necessary for glutamine inhibition of endothelial nitric oxide synthesis. Biochem. J 2001;353:245-252. [PubMed: 11139387]

21. Wu G. Synthesis of citrulline and arginine from $\square$ raline in enterocytes of postnatal pigs. Am. J. Physiol. Gastrointest. Liver Physiol 1997;272:G1382-G1390.

22. Jobgen WS, Fried SK, Fu FW, Meininger CJ, Wu G. Regulatory role for the arginine-nitric oxide pathway in metabolism of energy substrates. J. Nutr. Biochem 2006;17:571-588. [PubMed: 16524713]

23. Wei CC, Crane BR, Stuehr DJ. Tetrahydrobiopterin radical Enzymology. Chem. Rev 2003;103:23652383. [PubMed: 12797834]

24. Wu G, Fang YZ, Yang S, Lupton JR, Turner ND. Glutathione metabolism and its implications for health. J. Nutr 2004;134:489-492. [PubMed: 14988435] 
25. Thony B, Auerbach G, Blau N. Tetrahydrobiopterin biosynthesis, regeneration and functions. Biochem. J 2000;347:1-16. [PubMed: 10727395]

26. Kohli R, Meininger CJ, Haynes TE, Yan W, Self T, Wu G. Dietary L-arginine supplementation enhances endothelial nitric oxide synthesis in streptozotocin-induced diabetic rats. J. Nutr 2004;134:600-608. [PubMed: 14988454]

27. Wu G, Collins JK, Perkins-Veazie P, Siddiq M, Dolan KD, Kelly KA, Heaps CL, Meininger CJ. Dietary supplementation with watermelon pomace juice enhances arginine availability and ameliorates the metabolic syndrome in Zucker diabetic fatty rats. J. Nutr 2007;137:2680-2685. [PubMed: 18029483]

28. Clarke SD, Romsos DR, Leveille GA. Differential effects of dietary methyl esters of long-chain saturated and polyunsaturated fatty acids on rat liver and adipose tissue lipogenesis. J. Nutr 1977;107:1170-1181. [PubMed: 874561] 

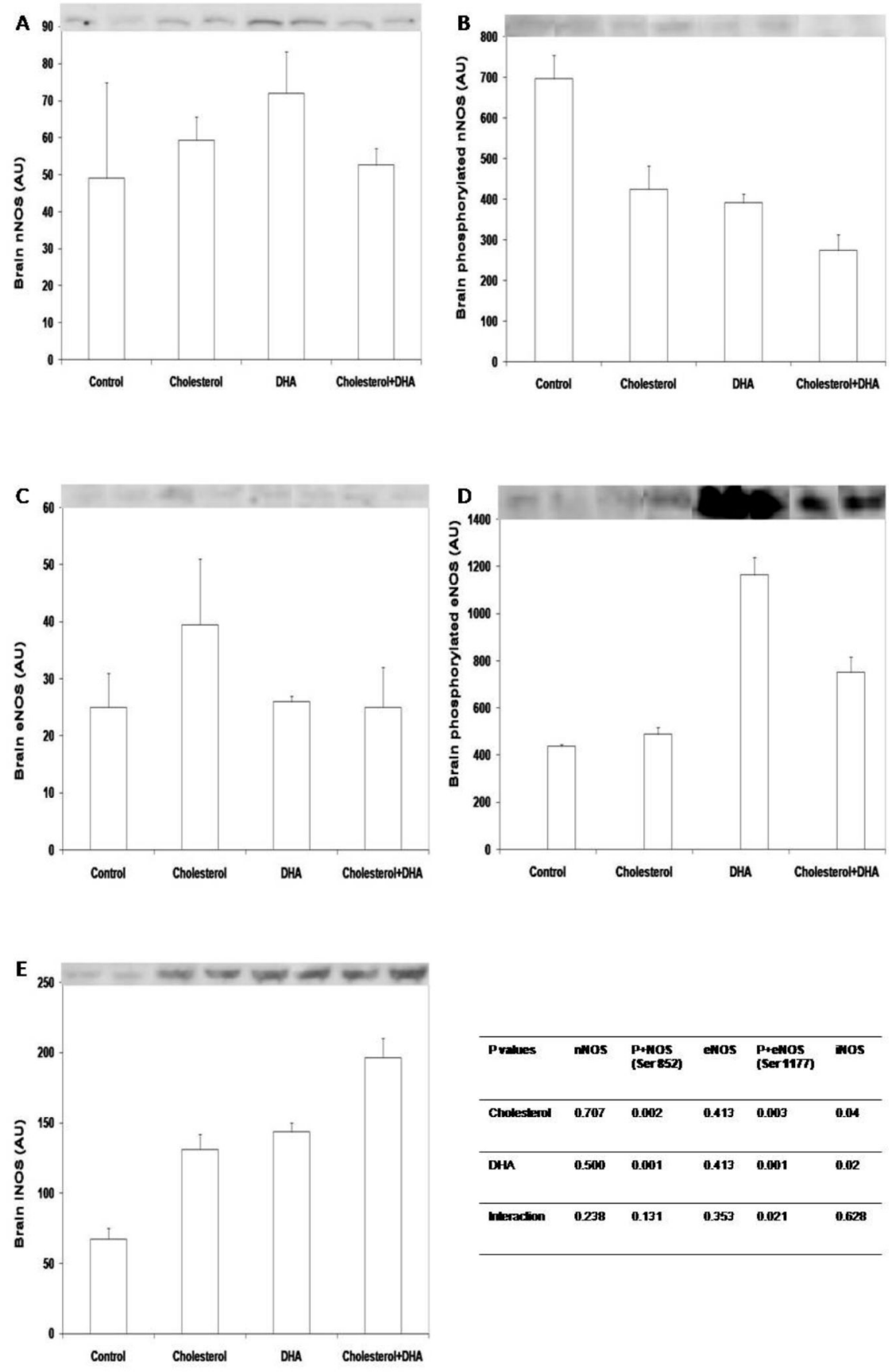

Figure 1.

Total nNOS (A), phosphorylated nNOS at Ser 852 (B), total eNOS (C), phosphorylated eNOS at Ser 1177 (D), and iNOS (E) in brain of piglets supplemented with cholesterol and DHA. Tissue lysate proteins $(60 \mu \mathrm{g})$ were solubilized in SDS-PAGE buffer and separated in 4-12\% polyacylamide gels. After transfer to nitrocellulose membrane, blots were probed with respective antibodies. Western blots are representatives of brain samples from 2 piglets per treatment. Data in bars are mean \pm SEM, $n=4$. P+eNOS, phosphorylated eNOS at Ser 1177; $\mathrm{P}+\mathrm{nNOS}$, phosphorylated nNOS at Ser 852. 

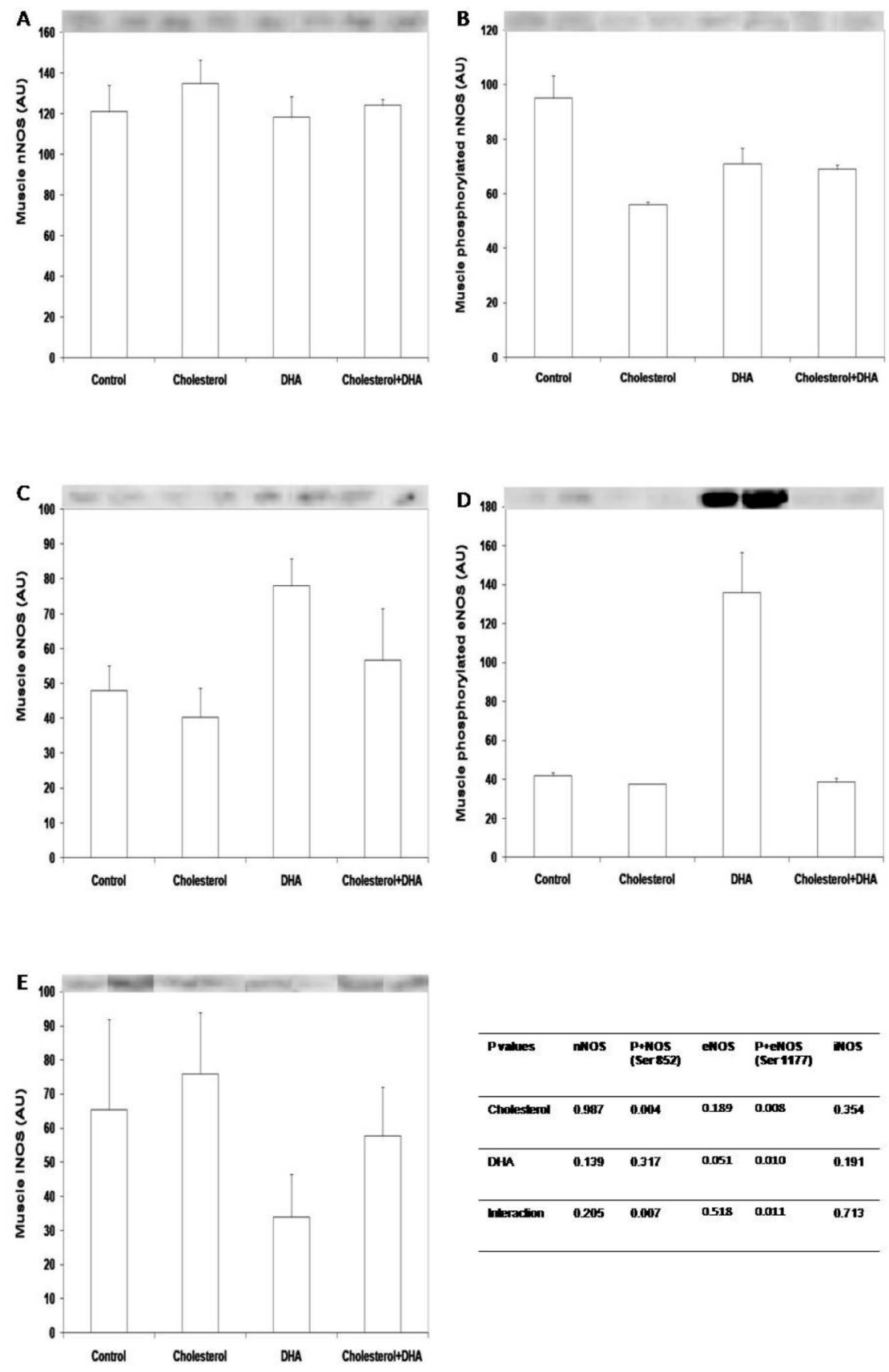

Figure 2.

Total nNOS (A), phosphorylated nNOS at Ser 852 (B), total eNOS (C), phosphorylated eNOS at Ser 1177 (D), and iNOS (E) in gastrocnemius muscle of piglets supplemented with cholesterol and DHA. Tissue lysate proteins $(30 \mu \mathrm{g})$ were solubilized in SDS-PAGE buffer and separated in 4-12\% polyacylamide gels. After transfer to nitrocellulose membrane, blots were probed with respective antibodies. Western blots are representatives of muscle samples from 2 piglets per treatment. Data in bars are mean $\pm S E M, n=4$. P+eNOS, phosphorylated eNOS at Ser 1177; P+nNOS, phosphorylated nNOS at Ser 852. 
Table 1

The Composition of diets ${ }^{l}$

\begin{tabular}{|c|c|c|c|c|}
\hline $\begin{array}{l}\text { Dietary cholesterol, } \% \\
\text { Dietary DHA, \% }\end{array}$ & $\begin{array}{c}0.0^{2} \\
0.0\end{array}$ & $\begin{array}{l}0.2 \\
0.0\end{array}$ & $\begin{array}{l}0.0 \\
0.2\end{array}$ & $\begin{array}{l}0.2 \\
0.2\end{array}$ \\
\hline \multicolumn{5}{|l|}{ Ingredient, $\%$} \\
\hline Coconut oil & 9.5 & 9.5 & 9.5 & 9.5 \\
\hline Soybean oil & 1.0 & 1.0 & 1.0 & 1.0 \\
\hline Soybean flour & 10.0 & 10.0 & 10.0 & 10.0 \\
\hline Calcium caseinate & 15.5 & 15.5 & 15.5 & 15.5 \\
\hline Whey (grade 1) & 50.1 & 50.1 & 50.1 & 50.1 \\
\hline Whey protein concentrate $(34 \% \mathrm{CP})$ & 5.0 & 5.0 & 5.0 & 5.0 \\
\hline Dicalcium phosphate $(22 \% \mathrm{P})$ & 1.7 & 1.7 & 1.7 & 1.7 \\
\hline Propylene glycol & 6.0 & 6.0 & 6.0 & 6.0 \\
\hline Merrick 2001 Spec FlavM ${ }^{3}$ & 0.1 & 0.1 & 0.1 & 0.1 \\
\hline Vitamin premix- $181^{4}$ & 0.25 & 0.25 & 0.25 & 0.25 \\
\hline Mineral premix 5 & 0.63 & 0.63 & 0.63 & 0.63 \\
\hline Choline chloride $50 \%$ WS & 0.05 & 0.05 & 0.05 & 0.05 \\
\hline Antioxidant-mold inhibitor mix ${ }^{6}$ & 0.10 & 0.10 & 0.10 & 0.10 \\
\hline Neomycin sulfate $100 \mathrm{~g} / \mathrm{Oxy}$ tetracycline $50 \mathrm{~g}$ & 0.07 & 0.07 & 0.07 & 0.07 \\
\hline $\begin{array}{l}\text { Cholesterol USP grade } \\
\text { S }\end{array}$ & 0.0 & 0.2 & 0.0 & 0.2 \\
\hline DHA $(20 \% \mathrm{wt} \%)^{7}$ & 0.0 & 0.0 & 1.0 & 1.0 \\
\hline
\end{tabular}

1 The basal diet was similar to that of Boleman et al. [3] and Schoknecht et al. [4], except that $1 \%$ soybean oil replaced $1 \%$ corn oil, and contained 3.31 Mcal metabolizable energy per kg diet.

2

2 Trace amounts of cholesterol were possibly provided by whey or whey protein concentrate, but quantity was negligible (less than $1 \mathrm{mg} / \mathrm{kg}$ ).

3 Non-nutritive sweetner (Merrick, Inc., Union Center, WI) to enhance palatability.

${ }^{4}$ Provided per kg diet: $8.3 \mathrm{mg}$ retinyl acetate, $55 \mu \mathrm{g}$ cholecalciferol, $44 \mathrm{mg}$ all-cis- $\boldsymbol{\alpha}$-tocopheryl acetate, $11 \mu \mathrm{g}$ vitamin B-12, $17.6 \mathrm{mg}$ D-pantothenic acid, $14 \mathrm{mg}$ niacin, $11 \mathrm{mg}$ menadione, $22 \mu \mathrm{g}$ biotin, and $66 \mathrm{mg}$ ascorbic acid.

5 Provided per kg diet: $844 \mu \mathrm{g}$ iodine, $47.9 \mu \mathrm{g}$ selenium, $2.3 \mathrm{mg}$ cobalt, $39.9 \mathrm{mg}$ copper, $24.1 \mathrm{mg}$ iron, $76 \mathrm{mg}$ magnesium, $3.5 \mathrm{mg}$ manganese, and 23.3 mg zinc.

${ }^{6}$ Butylated hydroxyanisole and propionic acid provided antioxidant and mold inhibition, respectively.

${ }^{7}$ The product (United Feeds, Inc., Sheridan, IN) was produced from fermentation of algae (Crypthecodimium $s p$ ) and was processed by spray-drying into a water-soluble powder containing $44 \%$ fat. The fatty acid composition of the product was as follows (\% as fed): myristic acid (C14:0), 4.5; palmitic acid (C16:0), 8.0; stearic acid (C18:0), 1.0; oleic acid (C18:1n9), 5.9; linoleic acid (C18:2n6), 0.8; arachidonic acid (C20:4n6), 1.1; eicosapentaenoic acid (C20:5n3), 0.2; docosapentaenoic acid (C22:5n3), 0.2; docosahexaenoic acid (DHA, C22:6n3), 20.2. 
Li et al.

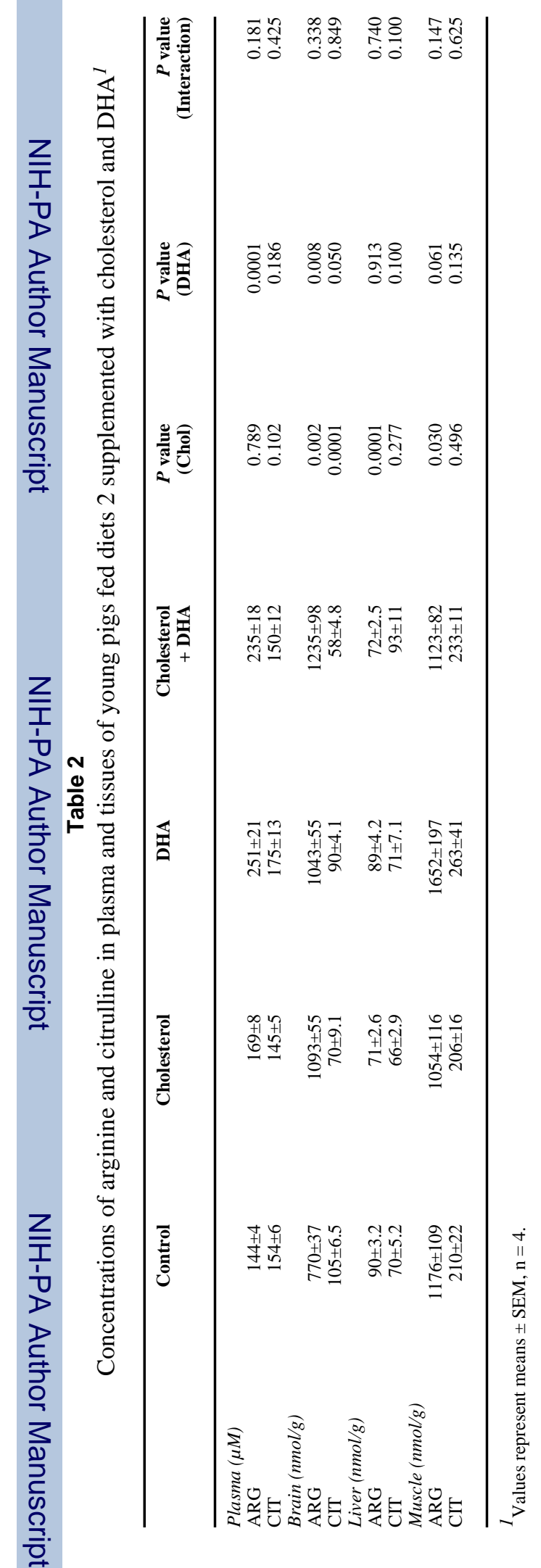

Nitric Oxide. Author manuscript; available in PMC 2009 November 1. 


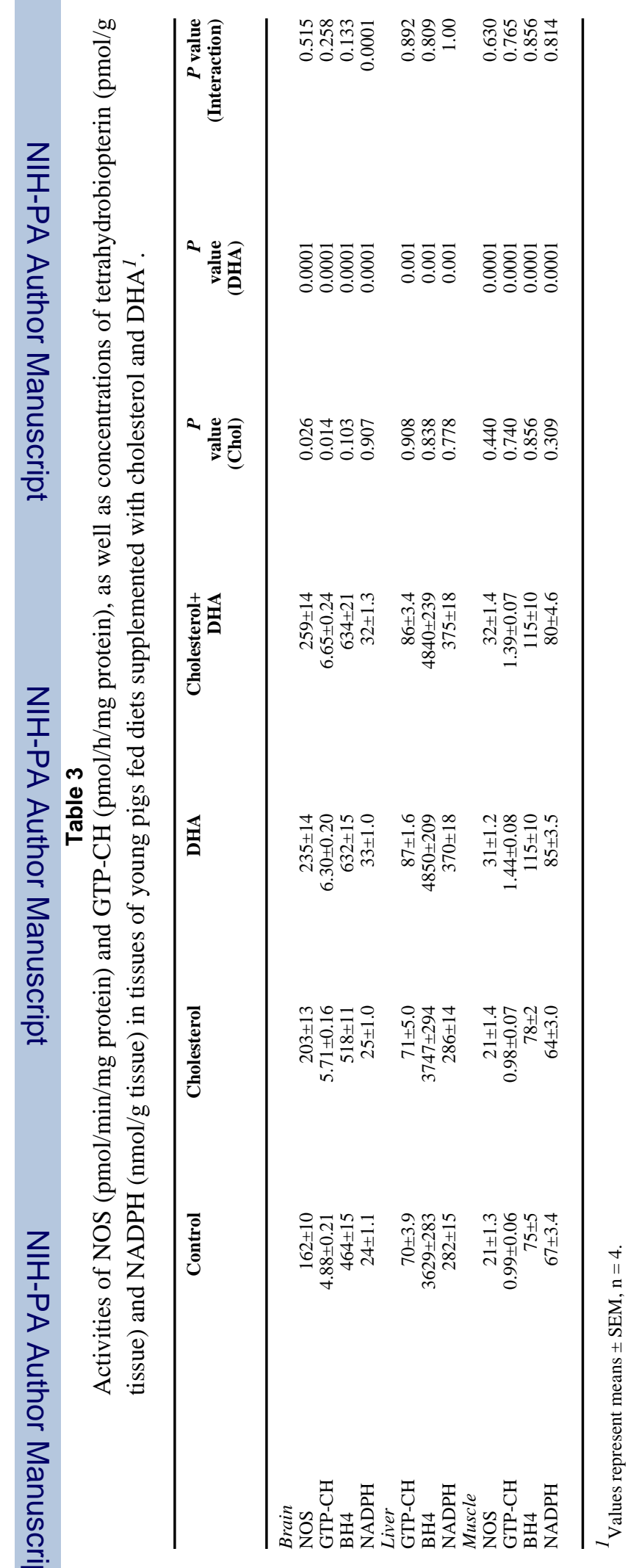

Nitric Oxide. Author manuscript; available in PMC 2009 November 1. 